\title{
The agrarian metabolism as a tool for assessing agrarian sustainability, and its application to Spanish agriculture (1960-2008)
}

\author{
Gloria I. Guzmán $^{1}, \underline{\text { Eduardo Aguilera }}^{1}, \underline{\text { Roberto García-Ruiz }}^{2}, \underline{\text { Eva Torremocha }}^{1}, \underline{\text { David Soto-Fernández }}^{1}$, Juan Infante-Amate $^{1}$ \\ and Manuel González de Molina ${ }^{1}$
}

\begin{abstract}
Agrarian metabolism applies the social metabolism framework to agriculture. It focuses on the study of the exchange of material and energy flows between a society and its environment for producing useful biomass. These flows must maintain the fund elements of the agroecosystem in sufficient quantity and of sufficient quality for them to continue providing ecosystem services. This methodology was applied to Spanish agriculture between 1960 and 2008, a period characterized by a deep process of intensification based on external inputs (EIs). We specifically focused on nitrogen $(\mathrm{N})$, phosphorus $(\mathrm{P})$, potassium $(\mathrm{K})$, carbon $(\mathrm{C})$, and energy flows, and on the three fund elements that they sustain such as soil, biodiversity, and woodland. The results show that the growing incorporation of EIs has broken the equilibrium between land and biomass uses required by traditional farming, lowering the density of internal energy loops. On cropland, the relative fall in unharvested biomass had a negative effect on both biodiversity and the soil, which reduced the replenishment of organic $\mathrm{C}$ between 1960 and 1990. The sharp increase in internal and external flows of biomass for animal feed hardly contributed to increasing soil organic carbon (SOC) between 1990 and 2008 because of the fact that these flows had increasingly lower C: $\mathrm{N}$ ratios. The massive importation of $\mathrm{N}$ in feed and mineral fertilizers (553 and $1150 \mathrm{Gg}$ in 2000 , respectively) increased the surplus and the losses of $\mathrm{N}$, which in turn could have a negative impact on biodiversity, water, and the atmosphere. The scenario constructed without imported animal feed would allow a reduction in the environmental impacts related to the excess of N, with hardly any negative effect on SOC replenishment, and improving energy return rates in the form of total, unharvested, and accumulated phytomass.
\end{abstract}

Key Words: agricultural intensification; agroecology; carbon and nutrient ( $N, P, K)$ balances; energy flows; social metabolism

\section{INTRODUCTION}

Agrarian metabolism (AM) refers to the exchange of energy and materials between a given society and its agrarian environment. It arises from the application of the social metabolism framework (Haberl et al. 2004, Giampietro et al. 2009) to agriculture, which implies the modification of some conceptual and methodological aspects of this framework. AM specializes in generating biomass and ecosystem services for human purposes (Guzmán Casado and González de Molina 2017). It is essential to know whether that exchange is carried out sustainably. This entails adding some crucial aspects to the metabolic schema.

First, our AM proposal considers the agroecosystem as the system of reference, understanding that agroecosystems are dissipative structures designed and managed by the farmers, through which flows of energy and materials enter, exit, and recirculate. The agroecosystem receives from its environment, natural and/or social, the energy and material fluxes that allow it to generate order in the form of biomass and environmental services that are useful for humans. An agroecosystem is, therefore, the outcome of a social-ecological relationship (Guzmán Casado and González de Molina 2017).

Second, we should distinguish between agroecosystem flow and funds, in accordance with the proposals put forward by Georgescu-Roegen (1971) and emphasized by Giampietro et al. (2009). The ultimate aim of the economy is not the production and consumption of goods and services, but rather the reproduction and improvement of the set of processes required for the production and consumption of goods and services. This variation in the main aim of economic agrarian activity implies, from a biophysical perspective, transferring the focus away from the flow of energy and materials and onto fund elements. This shift in orientation allows us to evaluate whether flows of energy and materials into and out of the agrarian sector are capable of reproducing and even improving fund elements in successive production cycles. In other words, moving the focus of attention away from the volume of production and consumption of biomass toward sustainability to ascertain whether production and consumption can be maintained indefinitely and, by extension, the supply of ecosystem services, because these also depend on the state of the agroecosystem fund elements (Cornell 2010, Burkhard et al. 2011, Costanza 2012).

Third, from a metabolic point of view, we have to analyze the role played by energy flows within agroecosystems, which is a crucial element when it comes to evaluating their sustainable functioning (Guzmán Casado and González de Molina 2017). Indeed, the socio-metabolic approach to agriculture is usually based on the domestic extraction (DE) of biomass, leaving the structure and functioning of ecosystems to one side. However, from an agroecological perspective, the level and sustainability of DE also depends on the biomass that is not extracted and that, therefore, remains within ecosystems and is available to their other heterotrophic components. It is well known that the sustainable management of an agroecosystem depends on the levels of biodiversity and organic matter, the appropriate replenishment of soil fertility, and the possibilities of closing biogeochemical cycles on a local scale, among other factors (Gliessman 1998). This represents a cost, because a significant part of the biomass generated must recirculate to perform the basic productive and reproductive functions of the agroecosystem: seeds, animal labor,

${ }^{1}$ Agro-Ecosystems History Laboratory, Universidad Pablo de Olavide (Seville), ${ }^{2}$ Department of Animal and Plant Biology and Ecology, Ecology Unit, Universidad de Jaén 
soil organic matter, biodiversity, and so forth. In accordance with the proposals of Ho and Ulanowicz $(2005: 41,45)$ and later of Ho (2013), the sustainability of agroecosystems, therefore, correlates positively with the quantity and quality of its internal loops or cycles and, to that extent, with the energy flows that circulate within them and whose function is to reproduce the fund elements. In short, the maintenance of internal loops in agroecosystems is directly related to the use of a significant part of net primary production to fuel them. This has major implications when it comes to calculating net primary productivity (NPP), which must then be broken down into different categories according to its productive or reproductive functionality (Guzmán Casado and González de Molina 2017).

To this extent, an agroecosystem with fund elements that require the dissipation of low levels of energy for its maintenance by means of those recirculation processes in turn generates low entropy in the surrounding environment and minimizes the flows of external energy. In contrast, when the internal complexity of an agroecosystem is substantially reduced, and its internal loops diminished, it needs to import energy in the generation of internal order. In these cases, total entropy also increases, and sustainability of agroecosystem could be compromised.

In other words, when agroecosystem functioning and the maintenance of the fund elements are based on a high density of internal loops, the imported flow of energy is also minimal. At the other extreme, when a complex agroecosystem is simplified to the point that it hosts a monoculture, external energy flows must be increased significantly (Government Office for Science 2011:10). This means that the capacity of the agroecosystem to maintain the production of biomass in the long term, without increasing inputs of external energy, is the foremost expression of sustainable management (Guzmán Casado and González de Molina 2017). Both criteria, the capacity to reproduce the biophysical fund elements or not and to do so without increasing the use of external energy, have been chosen by us to measure the environmental damage caused by the industrialization of agriculture.

The evaluation of the maintenance of fund elements allows us to recognize which of them are undergoing processes of deterioration and which are being improved and restored. In addition, it allows us to predict whether the modification of a flow to improve a fund element will harm another fund element and the extent to which there can be compensations between both uses. This is so because flows of energy and materials are interconnected. This analysis may provide new understandings on setting the limits of what is possible in terms of the degree of sustainability of an agroecosystem for given agroclimatic and technological conditions. The proposal thus becomes an intentional and dynamic model that interrelates the different components of the agroecosystem within a changing context. In short, our proposal considers agroecosystem as a holon (Bland and Bell 2007) whose connections must necessarily be explored. As Koestler stated in his seminal formulation of holon: "Organisms and societies are multi-leveled hierarchies of semiautonomous sub-wholes branching into sub-wholes of lower order and so on. The term holon has been introduced to refer to these intermediary entities which, relative to their subordinates in the hierarchy, function as self-contained wholes; relative to their superordinates as dependent parts. This dichotomy of wholeness and partness, of autonomy and dependence, is inherent in the concept of hierarchy order" (Koestler 1967:58). Therefore, the recognition of the complexity of agroecosystems as socialecological systems led to postulating a multiscalar analysis because of the hierarchical structure of organization.

On the other hand, the state of an agroecosystem cannot be considered as the sum total of the states of its fund elements. Therefore, results obtained after analyzing the state of different fund elements need to be consistent with a robust indicator that evaluates the agroecosystem as a whole. We used the actual net primary production energy return on investment (NPPact EROI; Guzmán and González de Molina 2015, Galán et al. 2016, Guzmán Casado and González de Molina 2017, Guzmán et al. 2017) because it has been shown to be a very consistent indicator when applied to different case studies and, therefore, permits the necessary methodological triangulation to test the other indicators and obtain more robust results.

We have applied this proposal to Spanish agriculture that represents Mediterranean agroenvironmental conditions over the past 50 years. During this period, Spanish agriculture experienced a substantial intensification process based on the use of external inputs to a greater extent than other Mediterranean countries. This circumstance makes Spanish agriculture an optimal case study, because it provides diachronic scenarios with very different land use intensities, within these agroenvironmental conditions. In particular, our objectives have been as follows: (a) to quantify the biophysical flows, i.e., energy, macronutrients, and carbon, of Spanish agriculture between 1960 and 2008; (b) to test whether these flows are capable of reproducing and even improving fund elements, i.e., soil, biodiversity, and woodland, in successive production cycles; and (c) to demonstrate the usefulness of this methodological approach for the design of sustainable agroecosystems, through its application to a scenario in which specific flows have been modified.

\section{DATA COLLECTION, CONCEPTS, AND METHODS}

\section{Data collection}

The main sources we used are the statistics provided by the Spanish government (MAGRAMA 2015). We have reconstructed the evolution of total biomass production in all Spanish land areas, excluding unproductive areas that remained practically constant throughout the period studied (see Table A1.1 in Appendix 1), and total inputs consumed (TIC) at six points over time between 1960 and 2008, using five-year averages to buffer year-on-year variability. The reconstruction of biomass production is described in detail in Soto et al. (2016) and Guzmán et al. (2017).

The exports and imports of biomass were calculated from foreign trade sources. For 1960 and 1990, we used the FAOSTAT database (FAO 2015). For the period from 2000 to 2008, we used the DATACOMEX database of Spanish overseas trade (MINECO 2015). The amounts of external inputs employed in Spanish agriculture during the period studied were mainly gathered directly from official statistics complemented by technical reports and research studies (Guzmán et al. 2017). 
Fig. 1. Energy flows in Spanish agroecosystem in 1960, 2000, and no-import scenario (in PJ).
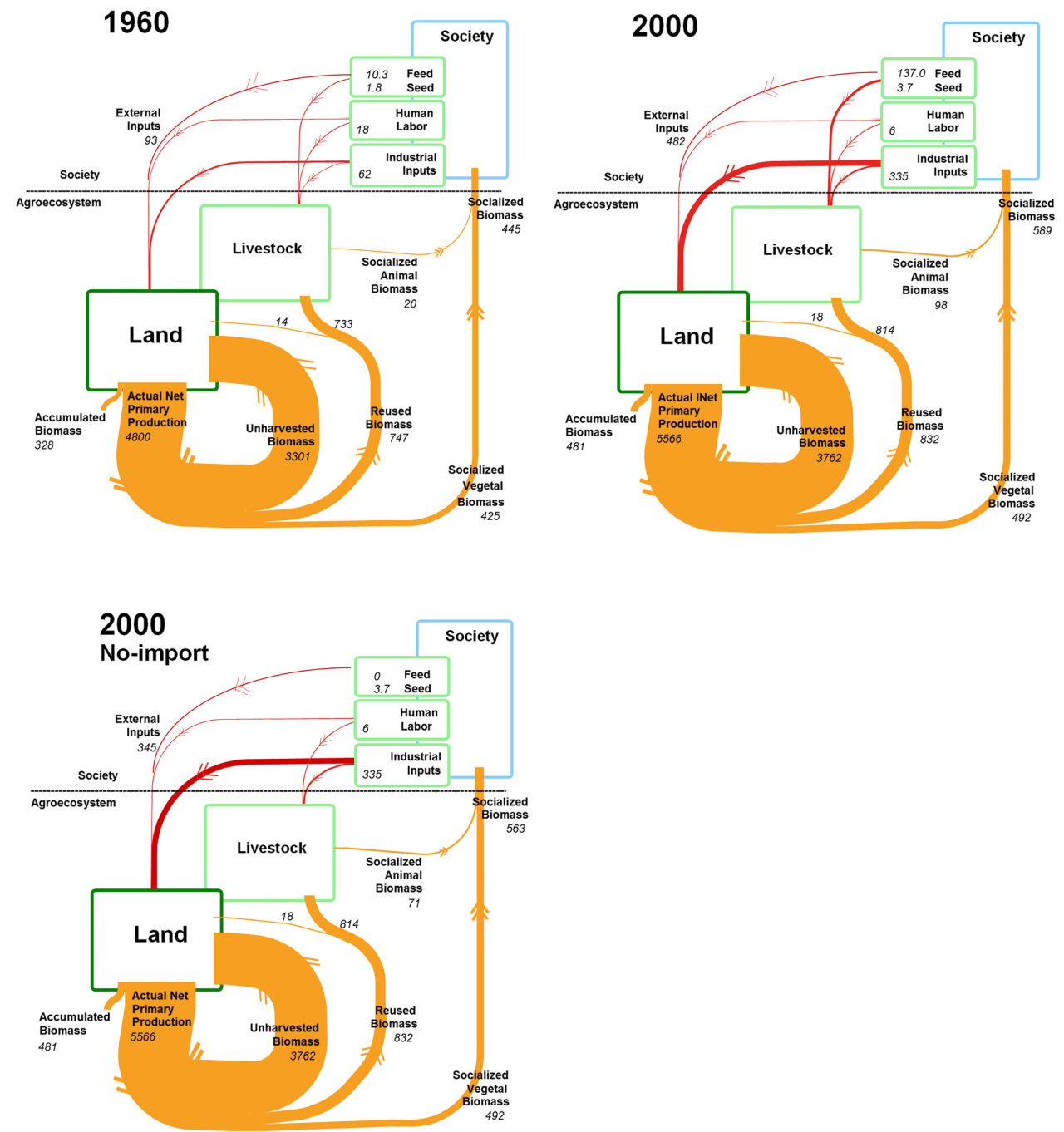

\section{Concepts}

NPPact is the net productivity that actually takes place in an existing ecosystem with human intervention, in contrast to that potential NPP that the ecosystem would achieve without human presence. It includes the root biomass as well as weeds.

Socialized vegetable biomass (SVB) is the phytomass that is directly appropriated by human society, considered as it is extracted from the agroecosystem, prior to its industrial processing. Socialized animal biomass (SAB) is the animal biomass, i.e., live weight of meat at the farm gate, milk, wool, and so forth, that is appropriated directly by society. The sum of SVB and SAB gives the socialized biomass (SB), which is the total biomass appropriated by society.

Reused biomass $(\mathrm{RuB})$ is the phytomass that is intentionally restored to the agroecosystem by the farmer. Therefore, the RuB does not cross the boundary between the agroecosystem and society (see Fig. 1). This means that the phytomass is reincorporated into the agroecosystem by means of human labor and has an agronomic purpose that is recognized by the farmer, for example, to obtain a product or a service, i.e., seeds and animal feed for the supply of meat or milk. This category includes the biomass that is destroyed by fire, for example, stubble burning, because it involves conscious work and has an agronomic purpose. $\mathrm{DE}$ is the sum of SVB and RuB.

Unharvested biomass ( $\mathrm{UhB}$ ) is the phytomass that is restored to the agroecosystem by abandonment, without the pursuit of any specific aim, and without the investment of any human work, for example, litterfall and the root systems, except in crops where the root is harvested. UhB can be divided into aboveground unharvested biomass (AUhB) and belowground unharvested biomass (BUhB).

Accumulated biomass $(\mathrm{AB})$ refers to the portion of phytomass that accumulates annually in the aerial structure and in the roots of perennial species, i.e., forest trees, woody crops, and shrubs. NPPact of agroecosystems is the sum of $\mathrm{SVB}+\mathrm{RuB}+\mathrm{UhB}+\mathrm{AB}$. 
External inputs (EIs) include human labor, as well as all of the inputs, i.e., fertilizer, pesticides, machinery, feed, and so forth, that originate outside the agroecosystem. They can be divided into industrial inputs, i.e., chemical fertilizers, machinery, and so forth, and nonindustrial inputs, i.e., phytomass, human labor, and so forth.

Usually, EROIs in agriculture have been used to measure the "energy cost" (Scheidel and Sorman 2012) of net biomass produced for appropriation by society (Martinez Alier 2011), whether in the form of foodstuffs, raw materials, or biofuels. However, it has recently been proposed to broaden its application to the assessment of agrarian sustainability. The EROIs developed to this end have been named "agroecological EROIs," and they estimate the return on the energy invested by society in the form of biomass flows that sustain agroecosystem fund elements. NPPact EROI, biodiversity EROI, and woodening EROI are agroecological EROIs. The methodology for agroecological EROI calculations was developed in Guzmán Casado and González de Molina (2017) and Guzmán et al. (2017).

NPPact EROI (Eq. 1) estimates the real productive capacity of the agroecosystem, whatever the origin of the energy it receives, i.e., solar for the biomass or fossil for an important portion of the EIs. This is an indicator that provides integrative information on the state of the agroecosystem, beyond the particular situation of each fund element. A decreasing trend in NPPact EROI values of an agroecosystem over time indicates degradation of the productive capacity.

\section{NPPact EROI $=$ NPPact/TIC $($ Eq. 1$)$}

Whereas TIC is calculated as RuB + UhB + EI. Biodiversity EROI provides useful information on the extent to which energy invested in the agroecosystem contributes to sustaining food chains of heterotrophic species, e.g., Arthropoda, Mammalia, and so forth, and is calculated according to Eq. 2. The relationship between energy flows and biodiversity has been proposed by ecologists based on empirical studies showing that ecosystems with larger amounts of energy entering the food web will be able to support longer food chains and hence greater biodiversity (Thompson et al. 2012). In the particular case of agroecosystems, different authors have found that the increase in forage resources is one of the drivers of the biodiversity increase associated with the conversion of conventional farms into organic farms in the present (Döring and Kromp 2003, Gabriel et al. 2013). A decreasing trend of this EROI indicates a deterioration of the biodiversity fund element.

\section{Biodiversity EROI = UhB/TIC (Eq. 2)}

Woodening EROI estimates whether the energy added to the system is contributing to the storing of energy in the system as AB. A decreasing trend in this EROI indicates a deterioration of the woodland fund element. This EROI is calculated as follows:

$$
\text { Woodening EROI = AB/TIC (Eq. 3) }
$$

\section{Methods}

Functioning of the agroecosystem

The calculation in energy terms of NPPact and its components, and of the EIs, can be found in detail in Guzmán Casado and González de Molina (2017) and Guzmán et al. (2017).
State of the fund elements

1. Soil: The maintenance of this fund element encompasses mainly two processes: the replenishment of nutrients (nitrogen $[\mathrm{N}]$, phosphorus $[\mathrm{P}]$, and potassium $[\mathrm{K}]$ ) and organic carbon. The first is based on flows of materials that might come from fossil fuels, such as mineral fertilizers, or through solar energy sources, such as manure, legumes, green manure, and so forth. The latter requires only flows from solar energy sources (biomass).

Replenishment of soil fertility (nitrogen [N], phosphorus [P], and potassium $[\mathrm{K}]$ ): $\mathrm{N}, \mathrm{P}$, and $\mathrm{K}$ budgets for the agricultural sector, i.e., cropland and pastureland, of the whole of Spain were performed every 10 years from 1960 to 2008. To this end, N, P, and $\mathrm{K}$ inputs and outputs in pastureland and cropland were accounted for. Input data of $\mathrm{N}, \mathrm{P}$, and $\mathrm{K}$ through a variety of synthetic fertilizers were obtained from the International Fertilizer Industry Association (https://www.fertilizer.org/). To estimate $\mathrm{N}$ input through atmospheric wet deposition, we followed the approach of Garcia-Ruiz et al. (2012), and we took into account the mean annual rainfall and nitrate and ammonium concentration of the rainwater of 17 weather stations distributed throughout Spain. $\mathrm{N}$ inputs via irrigation were estimated taking into account irrigation volume for agriculture and the concentration of available $\mathrm{N}$ in river water (water database of the European Environment Agency [EEA]; http://www.eea.europa.eu/data-and-maps). N fixation by the 28 main Spanish N-fixing crops was estimated. Fixed $\mathrm{N}$ was calculated from the total $\mathrm{N}$ biomass produced, including the belowground and aboveground unharvested part, and assuming that $60 \%$ (grand mean from the review of Gathumbi et al. [2002]) of that was fixed from the atmosphere. $\mathrm{N}$ fixation in pastureland was estimated from the mean annual aboveground biomass productivity of pastureland in the wet, dry, and semiarid regions of Spain and taking into account that legumes compromise $8.5 \%$ of that biomass on average (MMARM 2010). Manure N, P, and $K$ production was estimated based on the balance between $N, P$, and $\mathrm{K}$ ingestion and production. $\mathrm{N}, \mathrm{P}$, and $\mathrm{K}$ ingestion was calculated from the available feed, i.e., part of the harvest toward the livestock, imported feed, and grazing, and $\mathrm{N}$ contained in gross livestock production was estimated based on livestock dry matter production, multiplied by ratios of live weight to marketable products and N contents from Bodirsky et al. (2012).

The main outputs of $\mathrm{N}, \mathrm{P}$, and $\mathrm{K}$ from the cropland were as harvests, whereas in the case of pastures they were as grazed biomass. With respect to $\mathrm{N}$, denitrification, $\mathrm{NH}_{3}$ volatilization, and nitrate leaching were also accounted for. We estimated $\mathrm{N}, \mathrm{P}$, and $\mathrm{K}$ output in cropland by harvest for main cereals (18 cereal crops), grain legumes (16), potatoes, vegetables (39 crops), vineyards (for dessert and wine grapes), tree and fruit crops (40), olive orchards (for olive oil and table olives), textile and oil crops (17), sugarcane, miscellaneous crops (17), flavoring crops (4), and artificial pasture and forage crops (38) throughout the period studied from the yearbooks and reports of the Spanish Agriculture Ministry. This information together with N, P, and $\mathrm{K}$ contents of the edible harvest (U.S. Department of Agriculture [USDA] National Nutrient Database for Standard Reference and USDA Natural Resources Conservation Service; https://ndb.nal.usda.gov/ndb/search/list) was used to estimate the N, P, and K outputs of the harvest. Outputs of N, P, and K 
for pastureland were estimated from the grazed biomass taking into account the grazing livestock size and mean $\mathrm{N}, \mathrm{P}$, and $\mathrm{K}$ content of the grazed biomass. $\mathrm{N}$ lost by denitrification was mainly estimated from the synthetic $\mathrm{N}$ and manure $\mathrm{N}$ applied to cropland, or from excreted $\mathrm{N}$ on pastureland, taking into account Intergovernmental Panel on Climate Change (IPCC 2006) emission factors. $\mathrm{NH}_{3}$ volatilization was estimated from the EMEP/CORINAIR Emission Inventory Guidebook (EEA 2007), which provided default $\mathrm{NH}_{3}$ emission factors for different chemical $\mathrm{N}$ fertilizers and manure $\mathrm{N}$, and excreted $\mathrm{N}$ (for pastureland) once they have been applied. $\mathrm{N}$ nitrate lost through leaching was estimated from IPCC (2006) default values for synthetic $\mathrm{N}$ and manure $\mathrm{N}$ or excreted $\mathrm{N}$ application rates.

Replenishment of organic carbon: The soil organic carbon (SOC) model is an adaptation of the Henin-Dupuis model, with one active pool of soil organic matter, containing 58\% C (Mann 1986), which is mineralized at a constant rate each year and is replenished by inputs of carbon, each one with a specific humification coefficient. We did not attempt to estimate $\mathrm{C}$ sequestration rates in each time frame but preferred to assess the $\mathrm{C}$ balance in each time frame by calculating SOC stock at equilibrium in each land use category and for the whole territory. In this way, the uncertainty associated with the estimation of SOC stocks at a given time point, which is dependent on previous history, is avoided, while it still allows a fair comparison of the contribution of each management and land use arrangement to $\mathrm{C}$ stocks in the different time frames. We assumed that the active SOC mineralization rate was $1 \%$ on rain-fed soils and $2 \%$ on irrigated soils, based on Saña et al. (1996) and Sofo et al. (2005). We applied average values of $\mathrm{C}$ retention per unit $\mathrm{C}$ input (humification coefficients). Biomass production data, expressed as dry matter, were estimated as described in Soto et al. (2016). The carbon content of plant residues and external inputs were taken from Carranca et al. (2009), Boiffin et al. (1986), Rahn and Lillywhite (2002), Bilandzija et al. (2012), and Ono et al. (2009). Humification coefficients of herbaceous crop residues (average $12.5 \%$ for cereals and $8 \%$ for legumes) were based on a metaanalysis of carbon sequestration in Mediterranean soils (Aguilera et al. 2013) and other sources (Boiffin et al. 1986, Kätterer et al. 2011). In the case of woody crop residues, humification coefficients ( $36 \%$ on average) were based on data from Sofo et al. (2005) and Repullo et al. (2012). For external organic inputs (mainly manure), we used a humification coefficient of $31 \%$, which is the median value $(\mathrm{N}=25)$ of the percentage of $\mathrm{C}$ input contributing to net $\mathrm{C}$ sequestration in external organic input categories in Aguilera et al. (2013), and it also matches the data from Kätterer et al. (2011) and Andrén and Kätterer (1997). For roots, we assumed a humification coefficient of $39 \%$, based on Kätterer et al. (2011).

2. Biodiversity: The maintenance of this fund element was evaluated by the biodiversity EROI (see Guzmán Casado and González de Molina 2017, Guzmán et al. 2017).

3. Woodland: The maintenance of this fund element was evaluated by the woodening EROI (see Guzmán Casado and González de Molina 2017, Guzmán et al. 2017).

\section{Scenario without imported feed}

AM could be used as a systemic sustainability evaluation tool. It allows us to know the consequences for the functioning of agroecosystems and the quality of fund elements of any alteration of energy and material flows. As an example of this aspect, we have constructed a scenario of the year 2000, but without imported feed. The year 2000 was chosen because it marked the change of century and was clearly a precrisis period.

To this end, the metabolizable energy represented by animal feed was quantified, and the part of the livestock population that actually consumed it was subsequently eliminated. The impact of this elimination on biomass, carbon, and nutrient flows $(\mathrm{N}, \mathrm{P}$, and $\mathrm{K})$, as well as on the state of the fund elements, was then quantified.

\section{RESULTS}

\section{Functioning of the agroecosystem}

The beginning of the 1960s was a key period after which the modernization of Spanish agriculture accelerated. A first period, 1960-1986, can be distinguished, in which crop yields grew constantly as a result of the use of the complete package of the green revolution. In a second period, 1986-2008, the intensification process of Spanish agriculture continued, but its evolution was shaped by Spain's incorporation into the European Economic Community (1986). During this stage, Spanish agriculture became specialized in products with a higher demand in the European Union, i.e., olive oil, fruit, and vegetables. In parallel, low-productivity land was abandoned, generally grain cropland devoted to feed use and pastureland, whereas highprotein feed imports skyrocketed (Soto et al. 2016).

Between 1960 and 2008, the intensification of Spanish agriculture was based on the increase in EIs, and this meant multiplying the external energy invested in the agroecosystem by 5.5. This increase can be subdivided into several items. Although human labor input decreased to one-fifth, industrial inputs were multiplied by 5 , rising from 62 to $314 \mathrm{PJ}$, and imported biomass, mainly from Latin America, rose from 12 to 193 PJ (an increase of 1508\%; Fig. 1). Of this, $85 \%$ and $97 \%$ corresponded to feed, respectively, and the rest to seeds (Table A1.2 in Appendix 1).

Of the industrial inputs, energy used for crop protection grew the most during the period studied, by a factor of 35.2. It was followed by traction energy (which multiplied by 10.2), irrigation energy (by 7.7), and mineral fertilizers (by 2). This moderate increase in fertilizers was for two reasons. First, mineral fertilizers were an early addition to the Spanish agroecosystem. In fact, in 1960 they represented $62 \%$ of the energy of industrial inputs (Table A1.2 in Appendix 1). Second, this modest growth must be linked with a phenomenon inherent to semiarid agroecosystems typical of the Mediterranean: the lack of rainfall means that the application of more fertilizer is of limited use in terms of increasing NPPact in the absence of optimum hydric conditions. For this reason, its growth is also related to the rise in irrigation energy $(24 \%$ of industrial input in 2008) and in the irrigated land area, which rose by $82 \%$ between 1960 and 2008 . In energy terms, the introduction of mechanical technologies played a greater role, now accounting for $41 \%$ of industrial inputs (Table A1.2 in Appendix 1).

As a consequence of the increase in EIs, some limiting factors were overcome to a certain extent, e.g., nutrients, water, and so forth, and afforded greater protection against heterotrophic organisms, which translated into a greater NPPact (Fig. 1). 
Table 1. Actual net primary productivity, socialized animal biomass, external inputs, and agroecological energy return on investment (EROI) for the whole Spanish territory (in PJ).

\begin{tabular}{|c|c|c|c|c|c|c|c|}
\hline & 1960 & 1970 & 1980 & 1990 & 2000 & 2008 & No import \\
\hline Actual net primary productivity (NPPact) $(\mathrm{a}+\mathrm{c}+\mathrm{d}+\mathrm{e})$ & 4800.0 & 5073.0 & 4986.9 & 5215.9 & 5566.5 & 5625.2 & 5566.5 \\
\hline Socialized vegetable biomass $(S V B)($ a) & 425.2 & 412.0 & 396.4 & 478.2 & 491.6 & 505.7 & 491.6 \\
\hline Socialized vegetable biomass (cropland) & 234.6 & 264.7 & 300.1 & 341.3 & 356.5 & 341.3 & 356.5 \\
\hline Socialized vegetable biomass (forestland) & 190.6 & 147.3 & 96.2 & 136.9 & 135.0 & 164.4 & 135.0 \\
\hline Socialized animal biomass $(S A B)(\mathrm{b})$ & 20.2 & 35.8 & 54.9 & 72.6 & 97.7 & 105.9 & 97.7 \\
\hline Socialized biomass $(S B)(\mathrm{a}+\mathrm{b})$ & 445.3 & 447.8 & 451.2 & 550.8 & 589.3 & 611.5 & 589.3 \\
\hline Reused biomass $(R u B)(\mathrm{c})$ & 746.7 & 563.4 & 609.6 & 714.9 & 832.0 & 854.7 & 832.0 \\
\hline Unharvested biomass $(U h B)(\mathrm{d})$ & 3300.6 & 3671.3 & 3480.5 & 3560.7 & 3762.3 & 3798.4 & 3762.3 \\
\hline Aboveground unharvested biomass $(A U h B)$ & 1482.7 & 1778.6 & 1659.2 & 1713.1 & 1800.5 & 1825.4 & 1800.5 \\
\hline Belowground unharvested Biomass ( $B U h B)$ & 1817.9 & 1892.6 & 1821.3 & 1847.7 & 1961.8 & 1973.0 & 1961.8 \\
\hline Accumulated biomass $(A B)(\mathrm{e})$ & 327.6 & 426.2 & 500.4 & 462.1 & 480.5 & 466.5 & 480.5 \\
\hline External inputs $(E I)$ & 92.7 & 248.8 & 401.9 & 352.4 & 482.1 & 510.3 & 345.1 \\
\hline NPPact EROI $=N P P a c t /(R u B+U h B+E I)$ & 1.16 & 1.13 & 1.11 & 1.13 & 1.10 & 1.09 & 1.13 \\
\hline Biodiversity EROI $=U h B /(R u B+U h B+E I)$ & 0.80 & 0.82 & 0.77 & 0.77 & 0.74 & 0.74 & 0.76 \\
\hline Woodening EROI $=A B /(R u B+U h B+E I)$ & 0.08 & 0.10 & 0.11 & 0.10 & 0.09 & 0.09 & 0.10 \\
\hline
\end{tabular}

Fig. 2. Evolution of actual net primary production (in PJ) by its use in relative terms in Spanish cropland (a), Spanish pastureland (b), and Spanish forestland (c). AB, accumulated biomass; AUhB, aboveground unharvested biomass; BUhB, belowground unharvested biomass; RuB, reused biomass; SVB, socialized vegetable biomass.

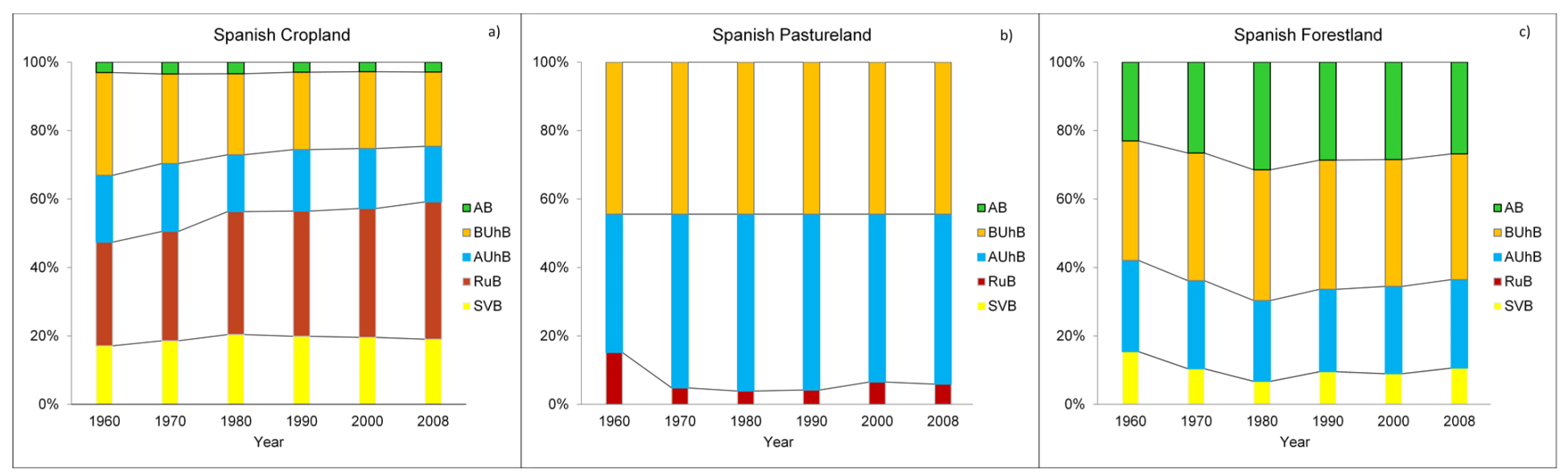

However, this growth was very moderate (17\%) and involved a negative return on the total energy invested to obtain that increase (NPPact EROI), which meant a certain degree of degradation of the Spanish agroecosystem (Table 1).

In addition, the growing use of EIs made it possible to modify the pattern of the social use of NPPact (Fig. 2). Basically, the $\mathrm{RuB}$ and $\mathrm{UhB}$ on cropland and pastureland were affected. The changes in RuB were driven by the large increase in the livestock population, mainly monogastric animals (porcine and avian), and the change from extensive to intensive farming (Soto et al. 2016). This profound change in the composition and management of livestock would not have been possible without the massive importation of feed, mainly soya and maize, which, for agroclimatic and economic reasons, was difficult to produce in Spain. In consequence, pastureland was partly abandoned. In parallel, growing amounts of high-quality biomass (grain and forage) from cropland have been devoted to livestock. On cropland, the RuB rose from 30\% of NPPact in 1960 to $40 \%$ in 2008. Meanwhile, on pastureland, it fell from $12 \%$ to $6 \%$ (Fig. 2). These imbalances in the intensity of land use, i.e., sharp intensification versus abandonment, were also seen inside the cropland. Over this period, the area of cropland fell by 3.1 Mha ( $15 \%$ of the total) mainly because of the abandonment of rainfed land with little response to EIs (Soto et al. 2016). The change in the pattern of social use of the biomass is also expressed in the increase in the burning of straw and other crop residues, mainly in the 1980s and 1990s, which were no longer used to feed livestock. Between 1960 and 1990, biomass burning in cropland rose from 0.6 to $3.6 \mathrm{Mt}$. This trend has been attenuated over the past 2 decades because of public policies addressed to restrict crop residue burning. Biomass burning fell from 3.6 to $1.3 \mathrm{Mt}$ dry matter between 1990 and 2008 .

Inversely, a smaller proportion of biomass is abandoned on cropland. The UhB fell from $50 \%$ of NPPact to $38 \%$. In relative 
Table 2. Nutrient balance (N, P, and K) for the different land uses and for the whole Spanish territory, 1960-2008 and no-import scenario.

\begin{tabular}{|c|c|c|c|c|c|c|c|c|c|c|c|c|c|c|}
\hline & 1960 & 1970 & 1980 & 1990 & 2000 & 2008 & No import & 1960 & 1970 & 1980 & 1990 & 2000 & 2008 & No-import \\
\hline & \multicolumn{7}{|c|}{$\mathrm{Gg} \mathrm{N}$} & \multicolumn{7}{|c|}{$\mathrm{kg} \mathrm{N} \mathrm{ha}^{-1}$} \\
\hline Cropland & 169 & 316 & 561 & 617 & 787 & 625 & 618 & 8.3 & 15.1 & 27.4 & 30.6 & 43.0 & 36.2 & 33.8 \\
\hline Grassland & 125 & 231 & 281 & 331 & 366 & 357 & 309 & 7.8 & 15.4 & 19.1 & 23.0 & 23.5 & 24.1 & 19.9 \\
\hline \multirow[t]{2}{*}{ Total } & 293 & 547 & 842 & 948 & 1152 & 982 & 927 & & & & & & & \\
\hline & \multicolumn{7}{|c|}{ Gg P } & \multicolumn{7}{|c|}{$\mathrm{kg} \mathrm{P} \mathrm{ha}^{-1}$} \\
\hline Cropland & 116 & 152 & 162 & 194 & 265 & 176 & 226 & 5.7 & 7.3 & 7.9 & 9.6 & 14.5 & 10.2 & 12.4 \\
\hline Grassland & -1 & 6 & 7 & 15 & 16 & 17 & 9 & $-0,1$ & 0.4 & 0.5 & 1.0 & 1.0 & 1.2 & 0.6 \\
\hline \multirow[t]{2}{*}{ Total } & 115 & 159 & 170 & 209 & 281 & 193 & 235 & & & & & & & \\
\hline & \multicolumn{7}{|c|}{ Gg K } & \multicolumn{7}{|c|}{$\mathrm{kg} \mathrm{K} \mathrm{ha}^{-1}$} \\
\hline Cropland & -108 & -69 & -40 & 55 & 214 & 142 & 106 & -5.3 & -3.3 & -2.0 & 2.7 & 11.7 & 8.2 & 5.8 \\
\hline Grassland & -132 & -7 & 5 & 47 & 22 & 29 & -11 & -8.3 & -0.5 & 0.3 & 3.3 & 1.4 & 2.0 & -0.7 \\
\hline Total & -240 & -76 & -35 & 102 & 236 & 170 & 95 & & & & & & & \\
\hline
\end{tabular}

terms, the reduction in BUhB was especially dramatic, falling by $9 \%$ (Fig. 2). This is a clear indication that the fertility of the soil has become the responsibility of mineral fertilizers, to the detriment of organic material. The use of herbicides is the main cause of this relative fall. On pastureland, however, UhB rose by $9 \%$ as a result of abandonment.

As a consequence of these processes, SB grew by $37 \%$ between 1960 and 2008, mainly because of the $425 \%$ increase in animal biomass. SVB grew by only $19 \%$, as the result of a $45 \%$ increase in SVB produced from crops but a fall of $14 \%$ in forest SVB (Table 1). The latter was reduced because of the substitution of firewood by fossil fuels in the home. On forestland, the lower extraction of firewood has contributed to an increase in $\mathrm{AB}$, which we have quantified at $45 \%$ (Table A1.3 in Appendix 1). The increase in cropland SVB $(45 \%)$ was greater than that seen in cropland NPPact $(30 \%)$. The increase in the harvest index of the varieties introduced in the green revolution contributed to this gap. The loss of the use of agrarian residue as animal feed and for the replenishment of soil fertility, as a result of the importation of external energy, is the driver of this modification in patterns of plant biomass partitioning.

Finally, the import of EIs allowed rotation to be simplified and the substitution of legumes, which were no longer essential to incorporate nitrogen into the agroecosystem. Between 1960 and 2000 , the crop area of legumes fell from 1.4 to $0.6 \mathrm{Mha}$. In parallel, $\mathrm{N}$ input by biological $\mathrm{N}$ fixation went from $28 \%$ of inputs to only $11 \%$ in the year 2000 , indicating a change in the agricultural model based on the application of EIs and not on a model reliant on biological N sources (Fig. 3).

\section{State of the fund elements}

\section{Soil}

Replenishment of soil fertility (N, P, and K) closing nutrient cycles on an agroecosystem scale: Between 1960 and 2008, Spain converted a relatively balanced equilibrium in $\mathrm{N}$ and $\mathrm{P}(\approx+8.3 \mathrm{~kg}$ $\mathrm{N} \mathrm{ha}^{-1} \mathrm{yr}^{-1}$ and $\approx+5.7 \mathrm{~kg} \mathrm{P} \mathrm{ha}^{-1} \mathrm{yr}^{-1}$ ) or a slightly deficit balance for $\mathrm{K}\left(\approx-5.3 \mathrm{~kg} \mathrm{~N} \mathrm{ha}^{-1} \mathrm{yr}^{-1}\right)$ on cropland into a significant surplus, and this was particularly true for $\mathrm{N}\left(\approx+43.0 \mathrm{~kg} \mathrm{~N} \mathrm{ha}^{-1} \mathrm{yr}^{-1}\right.$ in 2000 ; Table 2). The pattern of the increasingly positive balance from
Fig. 3. Nitrogen flows (Gg) in Spanish agroecosystem in 1960 and 2000 .
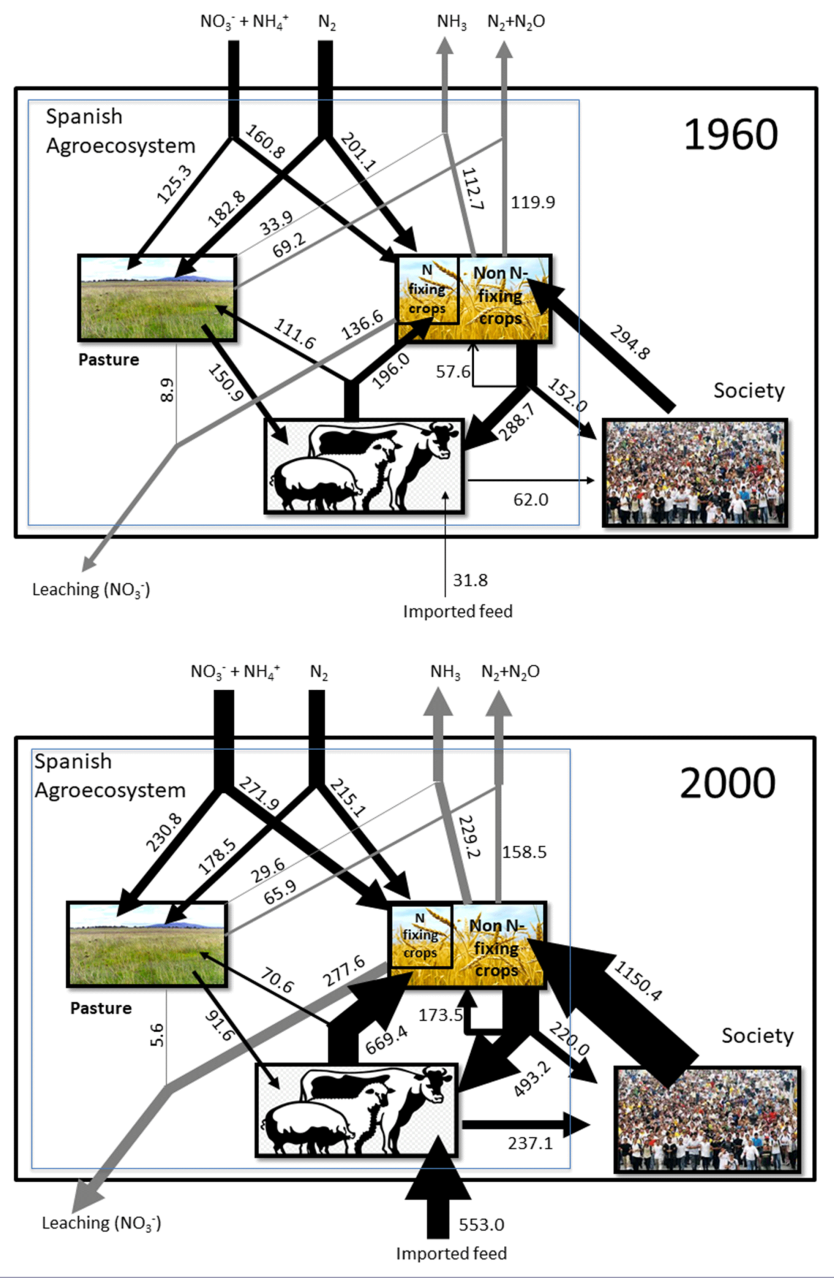

1960 onward was mainly because of the $3.2,1.3$, and 4.0 times 
Table 3. Soil organic carbon stocks at equilibrium for the different land uses and for the whole Spanish territory, 1960-2008 and noimport scenario.

\begin{tabular}{|c|c|c|c|c|c|c|c|}
\hline & 1960 & 1970 & 1980 & 1990 & 2000 & 2008 & No import \\
\hline & \multicolumn{7}{|c|}{$\operatorname{Tg~C}$} \\
\hline Cropland & 754 & 638 & 604 & 638 & 687 & 675 & 632 \\
\hline Grassland & 1415 & 1333 & 1230 & 1244 & 1422 & 1450 & 1422 \\
\hline Woodland & 745 & 891 & 866 & 873 & 930 & 951 & 930 \\
\hline \multirow[t]{2}{*}{ Total } & 2914 & 2862 & 2700 & 2756 & 3040 & 3076 & 2984 \\
\hline & \multicolumn{7}{|c|}{$\mathrm{MgC} \mathrm{ha}^{-1}$} \\
\hline Cropland & 36.9 & 30.6 & 29.5 & 31.7 & 37.6 & 39.1 & 34.6 \\
\hline Grassland & 88.9 & 88.7 & 83.6 & 86.5 & 91.5 & 92.7 & 91.5 \\
\hline Woodland & 74.4 & 81.9 & 74.8 & 71.7 & 74.3 & 70.7 & 74.3 \\
\hline Weighted average & 57.7 & 56.7 & 53.5 & 54.6 & 60.2 & 60.9 & 59.1 \\
\hline
\end{tabular}

increase in the application of $\mathrm{N}, \mathrm{P}$, and $\mathrm{K}$ in mineral fertilizers together with that applied as manure (Table A1.4 in Appendix 1). The increase in availability of imported manure boosted N, P, and $\mathrm{K}$ inputs on cropland, which multiplied by between 1.83 and 2.25 during that period. These increases in nutrient inputs on cropland did not see a concomitant increase in harvested nutrients as they only doubled during that period. Therefore, over the period studied, N, P, and $\mathrm{K}$ use efficiencies decreased from 0.54 to 0.39 , 0.42 to 0.35 , and 1.23 to 0.79 , respectively.

The decreasing trend in the $\mathrm{N}$ efficiency use of Spanish cropland over the period studied was concomitant with an increase in $\mathrm{N}$ losses per kilogram of harvested N. Certainly, although in 1960 $0.5 \mathrm{~kg} \mathrm{~N}$ was lost for each kilogram of harvested $\mathrm{N}$, this increased by $50 \%$ in $2000\left(0.73 \mathrm{~kg} \mathrm{~N}\right.$ loss $\mathrm{kg}^{-1}$ harvested $\left.\mathrm{N}\right) . \mathrm{N}_{2} \mathrm{O}$ emissions, which, in magnitude, are considered to be the third largest greenhouse gas contribution to stratospheric ozone layer depletion, increased by 2.7 during the study period, and figures were 2.0 and 3.0 for $\mathrm{NH}_{3}$ emissions and nitrate leaching on cropland (Table A1.5 in Appendix 1).

Replenishment of organic carbon: In both ecosystems and agroecosystems, the main driver of SOC is biomass input (Rodríguez-Martín et al. 2016). The fundamental difference is that, in agroecosystems, the magnitude of this input is both directly and indirectly conditioned by the farming method: directly, because many farming practices, such as residue burning, organic fertilization, use of herbicides, and so forth, intentionally modify the magnitude of the input; and indirectly, because the NPPact is affected by farming methods, to the extent that it affects the state of the fund elements and/or modifies the availability of limiting factors. Therefore, the SOC balance is the result of different processes that are, at times, contradictory.

Table 3 shows equilibrium SOC stocks in each time frame. Given that there are significant differences in SOC stocks between land uses, part of the change in total $\mathrm{C}$ stocks shown in Table 3 was because of land use changes, and part of it was because of changes in equilibrium $\mathrm{C}$ stocks in each type of land use. There was a marked drop in equilibrium SOC stocks in the period 1960-1980. This occurred particularly in cropland, and it was mainly because of the expansion of residue burning practices, herbicides, and tillage during this period, as well as the consolidation of varietal change. As from 1990, there was a recovery in cropland equilibrium SOC stocks, which surpassed the 1960 levels in 2000. This was attributable to, first, the restriction of crop residue burning; second, the increase in manure inputs because of the continued expansion of the livestock population; and, finally, the increase in unharvested residue, as a consequence of the greater NPPact and the decrease in the grazing of residue.

Biodiversity

Biodiversity EROI decreased by $8 \%$, indicating a decrease in UhB in relation to TIC, which entails a lower level of relative energy availability for wild heterotrophic organisms (Table 1). The change in the pattern of biomass use on cropland, mentioned previously, was responsible for this fall. The sharp increase in the amount of energy invested in cropland in the studied period increased NPPact by $30 \%$ in absolute terms, but the increase in productivity was invested mainly in $\mathrm{RuB}$, which grew by $73 \%$ (Table A1.3 in Appendix 1). The shift toward animal feed production had a negative impact on biodiversity. This effect was not compensated by the abandonment of pastureland and forestland. In short, the disassociation of the agroecosystem in areas of intensive production and abandoned and/or protected areas has not brought about a significant increase in the trophic energy available for transfer from plants to other levels in the food webs.

\section{Woodland}

Woodening EROI grew by 14\% between 1960 and 2008. That is, the growth rate of $\mathrm{AB}$ was higher than that of the energy invested in the agroecosystem. AB rose from 327.6 to $466.5 \mathrm{PJ}$. Of this growth $(138.9 \mathrm{PJ})$, approximately $7 \%$ corresponded to the expansion of woody crops (mainly almond and olive groves; 10.2 PJ). An additional 19\% (26.2 PJ) was because of the lower extraction of forestland SVB (Table 1). The remaining $74 \%$ of $\mathrm{AB}$ growth was because of the growth of forestland in areas freed from agricultural activities.

\section{Scenario without imported feed}

In the early 21 st century, imported feed was $38 \%$ of EIs and $21 \%$ of $\mathrm{N}$ inputs into the agroecosystem. Given its dimension, the alteration of this flow could substantially modify the functioning of the agroecosystem and the state of the fund elements. However, with respect to the functioning of the agroecosystem, because 
imported feed was fed to livestock, its elimination only directly affected the flow of SAB. Indirectly, it could affect the NPPact and its components bringing changes in the quality of the fund elements.

Table 1 shows that the SAB would be reduced by $27 \%$. This fall would mainly affect food produced from monogastric animals (pigs and poultry), because they are the main consumers of this feed. Given that the animals are poor energy converters, the impact on SB as a whole would be low (approximately 4\%).

Table 2 shows that the excess of $\mathrm{N}$ per hectare would be reduced by $21 \%$ on cropland and by a little less $(15 \%)$ on pastureland. This fall would bring with it a reduction of losses of $4 \%, 6 \%$, and $7.5 \%$ because of denitrification, volatilization, and leaching, respectively.

However, reduction in the livestock population in the "no feed import" scenario would not have a major effect on equilibrium SOC stocks on cropland (Table 3). This is because of the fact that this reduction is mainly focused on animal species whose manure is often managed in liquid forms, with a low $\mathrm{C}: \mathrm{N}$ ratio.

Finally, the agroecological EROIs calculated show a slight increase (Table 1). This is a consequence of the reduction of EIs and the maintenance of NPPact, because the elimination of imported feed does not cause any deterioration of the soil, and may even improve the state of other fund elements, as it would reduce $\mathrm{N}$ losses.

\section{DISCUSSION}

The pattern of agrarian intensification based on external energy, in comparison to intensification based on the increase of the density of low-entropy internal loops, became generalized in parallel to the implementation of the green revolution worldwide (González de Molina and Guzmán 2017). The case of Spain is no different from that of other countries. However, the high weighting of imported feed in EIs is less common. In fact, globally, Spain forms part of the leading group of countries in net nutrient, especially nitrogen, imports in the form of feed (Lassaletta, Billen, Grizzetti, et al. 2014), with much higher figures than neighboring countries such as France, where imported $\mathrm{N}$ used for animal feed in 2006 was $21 \%$ of the total nitrogen consumed by animals (Le Nöe et al. 2017), in comparison with Spain's $47 \%$ in 2000 . In contrast, other European countries, such as the Netherlands, Denmark, and Belgium, share Spain's intensive livestock farming methods, sustained by the import of large amounts of feed (Lassaletta, Billen, Romero, et al. 2014).

EIs have broken the relative equilibrium in the land and biomass uses required by traditional farming. In short, the shift toward $\mathrm{DE}(\mathrm{SVB}+\mathrm{RuB})$ versus $\mathrm{UhB}$ is based on several strategies. First, industrialized farming uses herbicides and/or intensive tillage to prevent the growth of phytomass that farmers are not interested in appropriating. Second, modern varieties, mainly cereals, have been selected to increase the harvest index (Sanchez-Garcia et al. 2013). Finally, the role of biomass in the maintenance of soil fertility was replaced, to a certain extent, by mineral fertilizers and pesticides, whose most extreme manifestation was the increase in crop residue burning. This loss of functionality allows us not only to break the balance between the different uses of biomass within a given space, e.g., cropland, but also to interrupt or reduce the biomass and nutrient flows between territories with different synchronic or diachronic uses, e.g., pastureland to cropland or between legumes and nonlegumes. The transfer of nutrients from pastureland and dry farming areas devoted to animal feed to more productive areas of cropland was not uncommon in traditional Mediterranean agriculture (Cussó et al. 2006, Guzmán Casado and González de Molina 2009). The process of intensification not only interrupted this dynamic, but also converted pastureland into the net recipient of nutrients throughout the importation of animal feed (Fig. 3).

With respect to the changes in biomass use patterns and agroecological EROIs, it is not possible to compare with other cases on a national scale, given the novelty of the methodology used. However, at the crop scale, the study of coffee in Costa Rica (1935 and 2005) reveals that intensification based on EIs gave rise to similar changes. The intensification of the coffee agroecosystem was accompanied by a small increase $(8 \%)$ in NPPact, which gave rise to a negative NPPact EROI return, and a sharp increase $(27 \%)$ in $\mathrm{RuB}$ and $\mathrm{AB}(95 \%)$, resulting in a notable increase in woodening EROI $(50 \%)$. In line with what has happened in Spain, the increase in such uses reduced the amount of biomass abandoned in the coffee fields (UhB; $-3 \%$ ), reducing the biodiversity EROI by $26 \%$ (Infante-Amate et al. 2017). On a local scale, these changes in biomass use patterns were also documented in Santa Fe (Granada, Spain) between 1934 and 1997. This municipality in the southeast of Spain represents one of the earliest and most profoundly intensified areas of the country (Guzmán Casado and González de Molina 2017). In this municipality, the trend of these EROIs was similar to what we found for Spain, with the exception of the NPPact EROI. In Santa $\mathrm{Fe}$, the NPPact EROI grew between 1934 and 1997, because of the sharp increase in water consumption and the expansion of crops with higher biomass production, such as poplar (Guzmán Casado and González de Molina 2017).

With regard to $\mathrm{N}$ fluxes, these results are similar to those of Leip et al. (2011) who found an $\mathrm{N}$ surplus for Spain in the period 2001-2003 of about $50 \mathrm{~kg} \mathrm{~N} \mathrm{ha}^{-1} \mathrm{yr}^{-1}$, slightly lower than the mean for the European Union-27 (EU-27). Our data on annual anthropogenic $\mathrm{N}$ inflows in 1960 (326 Gg N yr ${ }^{-1}$; chemical fertilizer plus imported $\mathrm{N}$ feed) and 2000 (1703 Gg N yr ${ }^{-1}$; Fig. 3) were similar to those calculated by Lassaletta, Billen, Romero et al. (2014) for the periods of 1961-1964 (405 Gg N yr ${ }^{-1}$ ) and 2000-2009 (1558 Gg N yr ${ }^{-1}$ ). In short, the Spanish agroecosystem went from a balanced equilibrium of macronutrients in 1960, in which $68 \%, 41 \%$, and $82 \%$ of $\mathrm{N}, \mathrm{P}$, and $\mathrm{K}$ flows took place within the agricultural sectors, to a very imbalanced situation in 2000 , when only $34 \%, 13 \%$, and $34 \%$, of the N, P, and K flows were provided by the agroecosystem itself. As well as growing dependence and lower efficiency, this imbalance led to significant losses of $\mathrm{N}$, which, because it is a mobile element, is not stored in the agroecosystem. This nutrient dissipates into the environment and cascades through air, water, and terrestrial ecosystems where it contributes to a multitude of effects, including adverse impacts on human health, ecosystem services, and climate change (Galloway et al. 2003, Erisman et al. 2013). $\mathrm{NH}_{3}$ volatilized from cropland in $2008(185 \mathrm{Gg} \mathrm{N})$ was higher than the value for the same year estimated by the official Spanish $\mathrm{N}$ balance (MAPAMA 2017), but lower than the value estimated by SanzCobena et al. (2014) using a more detailed approach. $\mathrm{NH}_{3}$ has a short atmospheric lifetime and is usually deposited near its source, 
contributing to the eutrophication of natural waters (Grizzetti et al. 2011), increased $\mathrm{N}$ input into natural terrestrial ecosystems, causing biogeochemical imbalances (van Herk et al. 2003), and increased susceptibility to stress and changes in soil and plant communities (Dise et al. 2011). Nitrate leaching is related to the eutrophication of ground and surface watercourses and estuaries (Fowler et al. 2013) and poses a recognized risk to human health. With regard to biodiversity, high $\mathrm{N}$ availability generally causes biodiversity decline in both terrestrial and aquatic ecosystems. The most widely reported consequences of available $\mathrm{N}$ enrichment in terrestrial ecosystems are declines in plant species richness and evenness (Suding et al. 2005, Bobbink et al. 2010). The proposed mechanism of a reduction in plant biodiversity driven by an excess of $\mathrm{N}$ availability includes ammonium toxicity, acidification, light exclusion, increased susceptibility to secondary stress factors, and changes to plant-soil feedback. The reduction of species biodiversity in aquatic ecosystems because of an excess of available $\mathrm{N}$ is related to eutrophication and water hypoxia driven by the high productivity of low diverse algal blooms promoted by high available N and P (Sala et al. 2000). Therefore, although this surplus does not affect the quality of the soil, it does negatively affect other fund elements such as water, biodiversity, and the atmosphere.

Regarding carbon, our estimations of SOC stocks at equilibrium are in line with published empirical studies reporting SOC stocks for the different land uses in Spain. Our estimation of SOC stocks in croplands of $34.5 \mathrm{MgC} \mathrm{ha}^{-1}$ on average for the period 1960-2008 is somewhat lower than the $43.5 \mathrm{Mg} \mathrm{C} \mathrm{ha}^{-1}$ estimated by Rodríguez-Martín et al. (2016) in a comprehensive assessment of SOC in Spanish croplands. In the case of grassland and forestland, our average values of 92.7 and $70.7 \mathrm{Mg} \mathrm{C} \mathrm{ha}^{-1}$, respectively, are between the values reported by Rodríguez-Martín et al. (2016) of 64.1 and 69.3, respectively, and those reported by DoblasMiranda et al. (2013) of 103.0 and 101.6, respectively.

The relatively low values in cropland indicate that agricultural land is on the threshold of degradation (Romanyà et al. 2007, Rodríguez-Martín et al. 2016). In theory, the increase in cropland NPPact resulting from intensification, together with the massive importation of feed, could have brought about a substantial increase in the return of organic carbon to the soil. However, the imbalance between biomass uses, depressing UhB, and the preferential use of feed for pigs and poultry prevented this from occurring.

On the other hand, in terms of SOC stock at equilibrium with respect to the recycled biomass in the cropland (cropland $\mathrm{RuB}+$ cropland $\mathrm{UhB}+$ imported feed consumed by the livestock on the cropland), the evolution was markedly negative. It fell from 685 $\mathrm{g} \mathrm{C} \mathrm{MJ}^{-1}$ in 1960 to $440 \mathrm{~g} \mathrm{C} \mathrm{MJ}^{-1}$ in 2008. In other words, it was necessary to recycle $56 \%$ more biomass to obtain the same SOC stocks in cropland. From the perspective of climate change mitigation, clearly the current biomass management strategy is not adequate.

In summary, the alteration of the functioning of the agroecosystem because of the intensification of EIs has directly encouraged the degradation of the soil and of biodiversity and, indirectly, of water, biodiversity and the atmosphere. The fall in the NPPact EROI reflects this deterioration, with cropland being the space most affected. Biodiversity could be especially harmed by the synergistic interaction between biomass and $\mathrm{N}$ fluxes. Furthermore, the increasing use of pesticides, whose effects we have not considered, would be added to this situation.

Woodland is the only fund element that evolves favorably, mainly as a result of the increase in $\mathrm{AB}$ in the forest. However, when examined in greater detail, it can be seen that the improvement occurred between 1960 and 1980. From then onward, this EROI began to see a significant fall. Once the process of substituting firewood as fuel was completed, i.e., a social change unconnected with the management of the agroecosystem, and the rate of change of the use of agricultural soil toward woody crops, which could not be indefinite, slowed down, the rate of growth in the amount of energy invested was much higher than that of AB. This occurred despite the fact that the continuous intensification of Spanish cropland meant that 3.5 Mha had been abandoned since 1980 (Table A1.1 in Appendix 1). This territory could theoretically be transformed into forest or shrubland, increasing the AB. However, the abandoned semiarid farmland was often close to degradation thresholds, which, in borderline agroclimatic conditions (semiarid, dry climate), do not recover but trigger the desertification of the territory (Loveland and Webb 2003, Romanyà et al. 2007). On the other hand, the liberation of Spanish territory for reforestation was because of the import of feed, mainly from Latin America (Lassaletta, Billen, Romero, et al. 2014), where it has possibly contributed to deforestation (Bettwy 2006).

From the social perspective, the return in the shape of SB cannot justify the unsustainable process of intensification that has been applied. In Spain, the most important driver of this shift was not the increase in the human population, but the rapid change in dietary patterns, which evolved from a typical Mediterranean diet to an animal protein-rich diet. The increase in the share of animal protein has been more intense, from $37 \%$ in the 1960 s to $65 \%$ today (Lassaletta, Billen, Romero, et al. 2014). This is significantly above World Health Organization recommendations (WHO 2007).

The reduction of SAB by $27 \%$ in the scenario without imported feed would bring an improvement in public health, a reduction in environmental impacts related to excessive nitrogen, with hardly any trade-off with the replenishment of SOC, and with an improvement in energy return rates in the form of total, unharvested, and accumulated phytomass.

\section{CONCLUSIONS}

The application of the metabolic approach to Spanish agriculture has shown that the intensification model based on EIs not only generates alterations in the relationship between input and output flows of energy and materials, which is how intensification has usually been evaluated, but also brings about significant changes in the internal functioning of the agroecosystem. In short, the reduction of the density of internal loops generated by new technologies has made the agroecosystem more dependent on external inputs, especially those from fossil fuels. These changes are perfectly captured by the AM framework.

A second conclusion is that the study of energy and material fluxes, which constitute the basis of social metabolism, allow us to explore the environmental impacts of agricultural industrialization, which had been out of the scope of metabolic 
methodologies so far. Our proposal on AM, in this sense, constitutes an innovation, incorporating tools that allow an assessment of the environmental impacts of a given type of management or a particular metabolic arrangement. In the Spanish case, the results show the deterioration of two of the fund elements studied: soil and biodiversity. This deterioration undermines the productive capacity of the agroecosystem, which is reflected by the NPPact EROI.

Third, given that the provision of ecosystem services by agroecosystems depends on the state of their fund elements, we can conclude that AM, through the assessment of the state of fund elements, allows us to inquire about the capacity of agroecosystems for provisioning ecosystem services. As we have demonstrated for the Spanish case, the deterioration of fund elements has reduced the provision of ecosystem services such as unpolluted water, carbon sequestration, or those derived from biodiversity, such as pest and disease control, which translates into a continued growth in pesticide use.

Finally, we consider that these results highlight the importance of choosing a correct strategy for agroecological intensification. The results obtained indicate that it is not simply a question of producing more biomass, but also of establishing the appropriate balance between different uses of that biomass and even between different animal species.

Responses to this article can be read online at: http://www.ecologyandsociety.org/issues/responses. $\mathrm{php} / 9773$

\section{Acknowledgments:}

This work springs from the international research project Sustainable Farm Systems: Long-Term Socio-Ecological Metabolism in Western Agriculture funded by the Social Sciences and Humanities Research Council of Canada (SSHRC 895-2011-1020) and Spanish research project HAR2015-69620C2-1-P funded by Ministerio de Economía y Competitividad (Spain).

\section{LITERATURE CITED}

Aguilera, E., L. Lassaletta, A. Gattinger, and B. S. Gimeno. 2013. Managing soil carbon for climate change mitigation and adaptation in Mediterranean cropping systems: a meta-analysis. Agriculture, Ecosystems and Environment 168:25-36. http://dx. doi.org/10.1016/j.agee.2013.02.003

Andrén, O., and T. Kätterer. 1997. ICBM: the introductory carbon balance model for exploration of soil carbon balances. Ecological Applications 7:1226-1236. http://dx.doi.org/10.1890/1051-0761 (1997)007[1226:ITICBM]2.0.CO;2

Bettwy, M. 2006. Growth in Amazon cropland may impact climate and deforestation patterns. National Aeronautics and Space Administration, Goddard Space Flight Center, Greenbelt, Maryland, USA. [online] URL: https://web.archive.org/ web/20081024151206/http://www.nasa.gov/centers/goddard/news/ topstory/2006/amazon_crops.html
Bilandzija, N., N. Voca, T. Kricka, A. Matin, and V. Jurisic. 2012. Energy potential of fruit tree pruned biomass in Croatia. Spanish Journal of Agricultural Research 10:292-298. http://dx.doi. org/10.5424/sjar/2012102-126-11

Bland, W. L., and M. M. Bell. 2007. A holon approach to agroecology. International Journal of Agricultural Sustainability 5(4):280-294.

Bobbink, R., K. Hicks, J. Galloway, T. Spranger, R. Alkemade, M. Ashmore, M. Bustamante, S. Cinderby, E. Davidson, F. Dentener, B. Emmett, J.-W. Erisman, M. Fenn, F. Gilliam, A. Nordin, L. Pardo, and W. De Vries. 2010. Global assessment of nitrogen deposition effects on terrestrial plant diversity: a synthesis. Ecological Applications 20:30-59. http://dx.doi. org/10.1890/08-1140.1

Bodirsky, B. L., A. Popp, I. Weindl, J. P. Dietrich, S. Rolinski, L. Scheiffele, C. Schmitz, and H. Lotze-Campen. 2012. $\mathrm{N}_{2} \mathrm{O}$ emissions from the global agricultural nitrogen cycle - current state and future scenarios. Biogeosciences 9:4169-4197. http://dx. doi.org/10.5194/bg-9-4169-2012

Boiffin, J., J. K. Zagbahi, and M. Sebillotte. 1986. Systèmes de culture et statut organique des sols dans le Noyonnais: application du modèle de Hénin-Dupuis. Agronomie 6:437-446. http://dx.doi. org/10.1051/agro:19860503

Burkhard, B., B. D. Fath, and F. Müller. 2011. Adapting the adaptive cycle: hypotheses on the development of ecosystem properties and services. Ecological Modelling 222:2878-2890. http://dx.doi.org/10.1016/j.ecolmodel.2011.05.016

Carranca, C., A. Oliveira, E. Pampulha, and M. O. Torres. 2009. Temporal dynamics of soil nitrogen, carbon and microbial activity in conservative and disturbed fields amended with mature white lupine and oat residues. Geoderma 151:50-59. http://dx.doi. org/10.1016/j.geoderma.2009.03.012

Cornell, S. 2010. Valuing ecosystem benefits in a dynamic world. Climate Research 45:261-272. http://dx.doi.org/10.3354/cr00843

Costanza, R. 2012. Ecosystem health and ecological engineering. Ecological Engineering 45:24-29. http://dx.doi.org/10.1016/j. ecoleng.2012.03.023

Cussó, J., R. Garrabou, and E. Tello. 2006. Social metabolism in agrarian region of Catalonia (Spain) in 1860-1870: flows, energy balance and land use. Ecological Economics 58:49-65. http://dx. doi.org/10.1016/j.ecolecon.2005.05.026

Dise N. B., M. Ashmore, S. Belyazid, A. Bleeker, R. Bobbink, W. de Vries, J. W. Erisman, T. Spranger, C. J. Stevens, and L. van den Berg. 2011. Nitrogen as a threat to European terrestrial biodiversity. Pages 463-494 in M. A. Sutton, C. M. Howard, J. W. Erisman, G. Billen, A. Bleeker, P. Grennfelt, H. van Grinsven, and B. Grizzetti, editors. The European nitrogen assessment: sources, effects and policy perspectives. Cambridge University Press, Cambridge, UK. http://dx.doi.org/10.1017/ CBO9780511976988.023

Doblas-Miranda, E., P. Rovira, L. Brotons, J. Martinez-Vilalta, J. Retana, M. Pla, and J. Vayreda. 2013. Soil carbon stocks and their variability across the forests, shrublands and grasslands of peninsular Spain. Biogeosciences 10:8353-8361. http://dx.doi. 


\section{org/10.5194/bg-10-8353-2013}

Döring, T. F., and B. Kromp. 2003. Which carabid species benefit from organic agriculture? A review of comparative studies in winter cereals from Germany and Switzerland. Agriculture, Ecosystems and Environment 98:153-161. http://dx.doi.org/10.1016/ $\underline{\mathrm{S} 0167-8809(03) 00077-\mathrm{X}}$

Erisman, J. W., J. N. Galloway, S. Seitzinger, A. Bleeker, N. B. Dise, A. M. R. Petrescu, A. M. Leach, and W. De Vries. 2013. Consequences of human modification of the global nitrogen cycle. Philosophical Transactions of the Royal Society, B: Biological Sciences 368:20130116. http://dx.doi.org/10.1098/ $\underline{\text { rstb.2013.0116 }}$

European Environment Agency (EEA). 2007. EMEP/ CORINAIR emission inventory guidebook - 2007. EEA Technical Report No. 16/2007. EEA, Copenhagen, Denmark.

Food and Agriculture Organization of the United Nations (FAO). 2015. FAOSTAT: FAO database for food and agriculture. FAO, Rome, Italy. [online] URL: http://faostat3.fao.org/

Fowler, D., M. Coyle, U. Skiba, M. A. Sutton, J. N. Cape, S. Reis, L. J. Sheppard, A. Jenkins, B. Grizzetti, J. N. Galloway, P. Vitousek, A. Leach, A. F. Bouwman, K. Butterbach-Bahl, F. Dentener, D. Stevenson, M. Amann, and M. Voss. 2013. The global nitrogen cycle in the twenty first century. Philosophical Transactions of the Royal Society, B: Biological Sciences 368:20130164. http://dx.doi.org/10.1098/rstb.2013.0164

Gabriel, D., S. M. Sait, W. E. Kunin, and T. G. Benton. 2013. Food production vs. biodiversity: comparing organic and conventional agriculture. Journal of Applied Ecology 50:355-364. http://dx.doi.org/10.1111/1365-2664.12035

Galán, E., R. Padró, I. Marco, E. Tello, G. Cunfer, G. I. Guzmán, M. González de Molina, F. Krausmann, S. Gingrich, V. Sacristán, and D. Moreno-Delgado. 2016. Widening the analysis of energy return on investment (EROI) in agro-ecosystems: socio-ecological transitions to industrialized farm systems (the Vallès County, Catalonia, c. 1860 and 1999). Ecological Modelling 336:13-25. http://dx.doi.org/10.1016/j.ecolmodel.2016.05.012

Galloway, J. N., J. D. Aber, J. W. Erisman, S. P. Seitzinger, R. W. Howarth, E. B. Cowling, and B. J. Cosby. 2003. The nitrogen cascade. BioScience 53:341-356. http://dx.doi.org/10.1641/0006-3568 (2003)053[0341:TNC]2.0.CO;2

García-Ruiz, R., M. González de Molina, G. I. Guzmán, D. Soto, and I. Infante-Amate. 2012. Guidelines for constructing nitrogen, phosphorus and potassium balances in historical agricultural systems. Journal of Sustainable Agriculture 36:650-682. http://dx. doi.org/10.1080/10440046.2011.648309

Gathumbi, S. M., G. Cadisch, and K. E. Giller. 2002. ${ }^{15} \mathrm{~N}$ natural abundance as a tool for assessing $\mathrm{N}_{2}$-fixation of herbaceous, shrub and tree legumes in improved fallows. Soil Biology and Biochemistry 34:1059-1071. http://dx.doi.org/10.1016/S0038-0717 (02)00038-X

Georgescu-Roegen, N. 1971. The entropy law and the economic process. Harvard University Press, Cambridge, Massachusetts, USA. http://dx.doi.org/10.4159/harvard.9780674281653

Giampietro, M., K. Mayumi, and J. Ramos-Martin. 2009. Multiscale integrated analysis of societal and ecosystem metabolism
(MuSIASEM): theoretical concepts and basic rationale. Energy 34:313-322. http://dx.doi.org/10.1016/j.energy.2008.07.020

Gliessman, S. R. 1998. Agroecology: ecological processes in sustainable agriculture. Ann Arbor, Chelsea, Michigan, USA.

González de Molina, M., and G. I. Guzmán. 2017. Agroecology and ecological intensification. A discussion from a metabolic point of view. Sustainability 9:86. http://dx.doi.org/10.3390/su9010086

Government Office for Science. 2011. The future of food and farming: challenges and choices for global sustainability. Final Project Report. Government Office for Science, London, UK.

Grizzetti, B., F. Bouraoui, G. Billen, H. van Grinsven, A. C. Cardoso, V. Thieu, J. Garnier, C. Curtis, R. Howarth, and P. Johnes. 2011. Nitrogen as a threat to European water quality. Pages 379-404 in M. A. Sutton, C. M. Howard, J. W. Erisman, G. Billen, A. Bleeker, P. Grennfelt, H. van Grinsven, and B. Grizzetti, editors. The European nitrogen assessment: sources, effects and policy perspectives. Cambridge University Press, Cambridge, UK. http://dx.doi.org/10.1017/CBO9780511976988.020

Guzmán, G. I., and M. González de Molina. 2015. Energy efficiency in agrarian systems from an agroecological perspective. Agroecology and Sustainable Food Systems 39:924-952. http://dx. doi.org/10.1080/21683565.2015.1053587

Guzmán, G. I., M. González de Molina, D. Soto Fernández, J. Infante-Amate, and E. Aguilera. 2017. Spanish agriculture from 1900 to 2008: a long-term perspective on agroecosystem energy from an agroecological approach. Regional Environmental Change, in press. http://dx.doi.org/10.1007/s10113-017-1136-2

Guzmán Casado, G. I., and M. González de Molina. 2009. Preindustrial agriculture versus organic agriculture: the land cost of sustainability. Land Use Policy 26:502-510. http://dx.doi. org/10.1016/j.landusepol.2008.07.004

Guzmán Casado, G. I., and M. González de Molina. 2017. Energy in agroecosystems: a tool for assessing sustainability. CRC, Boca Raton, FL, USA.

Haberl, H., M. Fischer-Kowalski, F. Krausmann, H. Weisz, and V. Winiwarter. 2004. Progress towards sustainability? What the conceptual framework of material and energy flow accounting (MEFA) can offer. Land Use Policy 21:199-213 http://dx.doi. org/10.1016/j.landusepol.2003.10.013

Ho, M.-W. 2013. Circular thermodynamics of organisms and sustainable systems. Systems 1:30-49. http://dx.doi.org/10.3390/ systems 1030030

Ho, M.-W., and R. Ulanowicz. 2005. Sustainable systems as organisms? BioSystems 82:39-51. http://dx.doi.org/10.1016/j. biosystems.2005.05.009

Infante-Amate, J., W. Picado, and G. I. Guzmán. 2017. Energy return on investment in traditional and modern agricultures: coffee agroecosystems in Costa Rica from an agroecological perspective (1935-2010). Pages 157-176 in G. I. Guzmán Casado and M. González de Molina, editors. Energy in agroecosystems. a tool for assessing sustainability. CRC, Boca Raton, FL, USA.

Intergovernmental Panel on Climate Change (IPCC). 2006. 2006 IPCC guidelines for national greenhouse gas inventories. Prepared 
by the National Greenhouse Gas Inventories Programme. H. S. Eggleston, L. Buendia, K. Miwa, T. Ngara, and K. Tanabe, editors. Institute for Global Environmental Strategies, Hayama, Japan.

Kätterer, T., M. A. Bolinder, O. Andrén, H. Kirchmann, and L. Menichetti. 2011. Roots contribute more to refractory soil organic matter than above-ground crop residues, as revealed by a longterm field experiment. Agriculture, Ecosystems and Environment 141:184-192. http://dx.doi.org/10.1016/j.agee.2011.02.029

Koestler, A. 1967. The ghost in the machine. Macmillan, New York, New York, USA.

Lassaletta, L., G. Billen, B. Grizzetti, J. Garnier, A. M. Leach, and J. N. Galloway. 2014. Food and feed trade as a driver in the global nitrogen cycle: 50-year trends. Biogeochemistry 118:225-241. http://dx.doi.org/10.1007/s10533-013-9923-4

Lassaletta, L., G. Billen, E. Romero, J. Garnier, and E. Aguilera. 2014. How changes in diet and trade patterns have shaped the $\mathrm{N}$ cycle at the national scale: Spain (1961-2009). Regional Environmental Change 14:785-797. http://dx.doi.org/10.1007/ s10113-013-0536-1

Leip, A., W. Britz, F. Weiss, and W. de Vries. 2011. Farm, land, and soil nitrogen budgets for agriculture in Europe calculated with CAPRI. Environmental Pollution 159:3243-3253. http://dx.doi. org/10.1016/j.envpol.2011.01.040

Le Noë, J., G. Billen, and J. Garnier. 2017. How the structure of agro-food systems shapes nitrogen, phosphorus, and carbon fluxes: the generalized representation of agro-food system applied at the regional scale in France. Science of the Total Environment 586:42-55. http://dx.doi.org/10.1016/j.scitotenv.2017.02.040

Loveland, P., and J. Webb. 2003. Is there a critical level of organic matter in the agricultural soils of temperate regions: a review. Soil and Tillage Research 70:1-18. http://dx.doi.org/10.1016/ $\underline{\mathrm{S} 0167-1987(02) 00139-3}$

Mann, L. K. 1986. Changes in soil carbon after cultivation. Soil Science 142:279-288. http://dx.doi.org/10.1097/00010694-198611000-00006

Martinez-Alier, J. 2011. The EROI of agriculture and its use by the Via Campesina. Journal of Peasant Studies 38(1):145-160. http://dx.doi.org/10.1080/03066150.2010.538582

Ministerio de Agricultura, Alimentación y Medio Ambiente (MAGRAMA). 2015. Anuarios de Estadística. MAGRAMA, Madrid, Spain. [online] URL: http://www.mapama.gob.es/es/ estadistica/temas/publicaciones/anuario-de-estadistica/

Ministerio de Agricultura y Pesca, Alimentación y Medio Ambiente (MAPAMA). 2017. Balance del nitrógeno en la agricultura española. Serie histórica 1990-2013. MAPAMA, Madrid, Spain. [online] URL: http://www.mapama.gob.es/es/ agricultura/temas/medios-de-produccion/productos-fertilizantes/

Ministerio de Economía y Competitividad (MINECO). 2015. DATACOMEX: Estadísticas del comercio exterior español. MINECO, Madrid, Spain. [online] URL: http://www.comercio. gob.es/es-ES/comercio-exterior/estadisticas-informes/Paginas/Informesde-Comercio-Exterior.aspx.

Ministerio de Medio Ambiente, Rural y Marino (MMARM).
2010. Balance del nitrógeno en la agricultura española. Año 2008. MMARM, Madrid, Spain.

Ono, K., K. Hirai, S. Morita, K. Ohse, and S. Hiradate. 2009. Organic carbon accumulation processes on a forest floor during an early humification stage in a temperate deciduous forest in Japan: evaluations of chemical compositional changes by ${ }^{13} \mathrm{C}$ NMR and their decomposition rates from litterbag experiment. Geoderma 151:351-356. http://dx.doi.org/10.1016/j.geoderma.2009.05.001

Rahn, C. R., and R. D. Lillywhite. 2002. A study of the quality factors affecting the short-term decomposition of field vegetable residues. Journal of the Science of Food and Agriculture 82:19-26. http://dx.doi.org/10.1002/jsfa.1003

Repullo, M. A., R. Carbonell, J. Hidalgo, A. Rodriguez-Lizana, and R. Ordoñez. 2012. Using olive pruning residues to cover soil and improve fertility. Soil and Tillage Research 124:36-46. http:// dx.doi.org/10.1016/j.still.2012.04.003

Rodríguez-Martín, J. A., J. Álvaro-Fuentes, J. Gonzalo, C. Gil, J. J. Ramos-Miras, J. M. Grau Corbí, and R. Boluda. 2016. Assessment of the soil organic carbon stock in Spain. Geoderma 264(Part A):117-125. http://dx.doi.org/10.1016/j.geoderma.2015.10.010

Romanyà, J., P. Rovira, and R. Vallejo. 2007. Análisis del carbono en los suelos agrícolas de España. Aspectos relevantes en relación a la reconversión a la agricultura ecológica en el ámbito mediterráneo. Ecosistemas 16(1):50-57.

Sala, O. E., F. S. Chapin, III, J. J. Armesto, E. Berlow, J. Bloomfield, R. Dirzo, E. Huber-Sanwald, L. F. Huenneke, R. B. Jackson, A. Kinzig, R. Leemans, D. M. Lodge, H. A. Mooney, M. Oesterheld, N. L. Poff, M. T. Sykes, B. H. Walker, M. Walker, D. H. Wall. 2000. Global biodiversity scenarios for the year 2100 . Science 287:1770-1774. http://dx.doi.org/10.1126/science.287.5459.1770

Saña, J., J. C. More, and A. Cochí. 1996. La gestión de la fertilidad de los suelos. Ministerio de Agricultura, Pesca y Alimentación, Madrid, Spain.

Sanchez-Garcia, M., C. Royo, N. Aparicio, J. A. Martín-Sánchez, and F. Álvaro. 2013. Genetic improvement of bread wheat yield and associated traits in Spain during the 20th century. Journal of Agricultural Science 151:105-118. http://dx.doi.org/10.1017/ S0021859612000330

Sanz-Cobena, A., L. Lassaletta, F. Estellés, A. Del Prado, G. Guardia, D. Abalos, E. Aguilera, G. Pardo, A. Vallejo, M. A. Sutton, J. Garnier, and G. Billen. 2014. Yield-scaled mitigation of ammonia emission from $\mathrm{N}$ fertilization: the Spanish case. Environmental Research Letters 9:125005. http://dx.doi. org/10.1088/1748-9326/9/12/125005

Scheidel, A., and A. H. Sorman. 2012. Energy transitions and the global land rush: ultimate drivers and persistent consequences. Global Environmental Change 22(3):588-595. http://dx.doi. org/10.1016/j.gloenvcha.2011.12.005

Sofo, A., V. Nuzzo, A. M. Palese, C. Xiloyannis, G. Celano, P. Zukowskyj, and B. Dichio. 2005. Net $\mathrm{CO}_{2}$ storage in Mediterranean olive and peach orchards. Scientia Horticulturae 107:17-24. http://dx.doi.org/10.1016/j.scienta.2005.06.001

Soto, D., J. Infante-Amate, G. I. Guzmán, A. Cid, E. Aguilera, 
R. García, and M. González de Molina. 2016. The social metabolism of biomass in Spain, 1900-2008: from food to feedoriented changes in the agro-ecosystems. Ecological Economics 128:130-138. http://dx.doi.org/10.1016/j.ecolecon.2016.04.017

Suding, K. N., S. L. Collins, L. Gough, C. Clark, E. E. Cleland, K. L. Gross, D. G. Milchunas, S. Pennings. 2005. Functional- and abundance-based mechanisms explain diversity loss due to $\mathrm{N}$ fertilization. Proceedings of the National Academy of Sciences of the United States of America 102(12):4387-4392. http://dx.doi. org/10.1073/pnas.0408648102

Thompson, R. M., U. Brose, J. A. Dunne, R. O. Hall, Jr., S. Hladyz, R. L. Kitching, N. D. Martinez, H. Rantala, T. N. Romanuk, D. B. Stouffer, and J. M. Tylianakis. 2012. Food webs: reconciling the structure and function of biodiversity. Trends in Ecology and Evolution 27(12):689-697. http://dx.doi.org/10.1016/ j.tree.2012.08.005

van Herk, C. M., E. A. M. Mathijssen-Spiekman, and D. deZwart. 2003. Long distance nitrogen air pollution effects on lichens in Europe. Lichenologist 35:347-359. http://dx.doi.org/10.1016/ $\underline{\text { S0024-2829(03)00036-7 }}$

World Health Organization (WHO). 2007. Protein and amino acid requirements in human nutrition. WHO Technical Report Series No. 935. WHO, Geneva, Switzerland. 


\section{Appendix 1}

Biophysical macro magnitudes of Spanish agriculture (1960-2008 and Scenario without imported feed)

Table A1.1. Land uses evolution (Mha), Spain

\begin{tabular}{|c|c|c|c|c|c|c|}
\hline & 1960 & 1970 & 1980 & 1990 & 2000 & 2008 \\
\hline Cropland & 20 & 21 & 20 & 20 & 18 & 17 \\
\hline Closed Forest & 5 & 6 & 7 & 7 & 7 & 8 \\
\hline Coppice & 5 & 5 & 5 & 5 & 5 & 5 \\
\hline Dehesa & 3 & 4 & 4 & 4 & 4 & 4 \\
\hline $\begin{array}{l}\text { Pastures and } \\
\text { Shrubland }\end{array}$ & 13 & 11 & 11 & 11 & 12 & 11 \\
\hline Unproductive & 4 & 4 & 4 & 4 & 4 & 4 \\
\hline Total & 50 & 50 & 50 & 50 & 50 & 50 \\
\hline
\end{tabular}


Table A1.2. External inputs evolution (TJ), Spain

\begin{tabular}{lccccccc}
\hline & 1960 & 1970 & 1980 & 1990 & 2000 & 2008 & No-import \\
\hline External Inputs (EI)(a+e) & 92,690 & 248,832 & 401,945 & 352,368 & 482,101 & 510,260 & 345,112 \\
Non-industrial Inputs (a) = b+c+d & 30,505 & 68,799 & 137,283 & 61,149 & 146,955 & 196,434 & 9,966 \\
Feed (b) & 10,289 & 53,403 & 124,365 & 51,822 & 136,989 & 187,842 & 0 \\
Seed (c) & 1,785 & 0 & 557 & 0 & 3,674 & 5,335 & 3,674 \\
Human Labor (d) & 18,431 & 15,396 & 12,361 & 9,327 & 6,292 & 3,257 & 6,292 \\
Industrial Inputs (e) $=\mathrm{f}+\mathrm{g}+\mathrm{h}+\mathrm{i}$ & 62,185 & 180,033 & 264,662 & 291,219 & 335,146 & 313,826 & 335,146 \\
Traction (f) & 12,764 & 81,696 & 124,785 & 103,296 & 116,318 & 129,666 & 116,318 \\
Irrigation (g) & 9,769 & 20,712 & 37,435 & 58,565 & 77,110 & 75,407 & 77,110 \\
Fertilizers (h) & 38,768 & 75,241 & 93,842 & 104,988 & 112,039 & 77,618 & 112,039 \\
Crop protection (i) & 884 & 2,385 & 8,599 & 24,369 & 29,679 & 31,135 & 29,679 \\
\hline
\end{tabular}


Table A1.3. NPPact evolution in cropland, pastureland and forestland (TJ), Spain

\begin{tabular}{lcccccc}
\hline & \multicolumn{7}{c}{ Cropland } & & & \\
\hline & 1960 & 1970 & 1980 & 1990 & 2000 & 2008 \\
\hline NPPact & $1,371,287$ & $1,426,425$ & $1,471,174$ & $1,715,584$ & $1,821,935$ & $1,793,445$ \\
Socialized Vegetable Biomass (SVB) & 234,616 & 264,716 & 300,139 & 341,307 & 356,544 & 341,303 \\
Reused Biomass (RuB) & 415,610 & 456,273 & 528,539 & 628,004 & 686,282 & 719,606 \\
Aboveground Un-harvested Biomass (AUhB) & 267,260 & 283,029 & 244,192 & 307,763 & 319,000 & 292,004 \\
Belowground Un-harvested Biomass (BUhB) & 411,991 & 373,179 & 348,298 & 388,219 & 409,708 & 388,481 \\
Accumulated Biomass (AB) & 41,811 & 49,227 & 50,006 & 50,291 & 50,401 & 52,050 \\
\hline & & Pastureland & & & 2000 \\
\hline & 1960 & 1970 & 1980 & 1990 & 2000 \\
\hline NPPact & $2,188,886$ & $2,227,802$ & $2,084,407$ & $2,061,839$ & $2,234,369$ & $2,284,455$ \\
Socialized Vegetable Biomass (SVB) & 0 & 0 & 0 & 0 & 0 & 0 \\
Reused Biomass (RuB) & 331,060 & 107,174 & 81,060 & 86,875 & 145,724 & 135,058 \\
Aboveground Un-harvested Biomass (AUhB) & 884,988 & $1,130,494$ & $1,076,944$ & $1,058,591$ & $1,095,592$ & $1,134,084$ \\
Belowground Un-harvested Biomass (BUhB) & 972,838 & 990,134 & 926,403 & 916,373 & 993,053 & $1,015,313$ \\
Accumulated Biomass (AB) & 0 & 0 & 0 & 0 & 0 & 0 \\
\hline
\end{tabular}




\begin{tabular}{lcccccc}
\hline \multicolumn{7}{c}{ Forestland } \\
\hline NPPact & 1960 & 1970 & 1980 & 1990 & 2000 & 2008 \\
Socialized Vegetable Biomass (SVB) & $1,239,886$ & $1,418,681$ & $1,431,276$ & $1,438,500$ & $1,510,151$ & $1,547,289$ \\
Reused Biomass (RuB) & 190,569 & 147,312 & 96,234 & 136,899 & 135,020 & 164,358 \\
Aboveground Un-harvested Biomass (AUhB) & 330,472 & 365,113 & 338,098 & 346,726 & 385,922 & 399,289 \\
Belowground Un-harvested Biomass (BUhB) & 433,070 & 529,328 & 546,562 & 543,066 & 559,067 & 569,212 \\
Accumulated Biomass (AB) & 285,775 & 376,927 & 450,383 & 411,809 & 430,142 & 414,430 \\
\hline
\end{tabular}


Table A1.4. Inputs of N, P and K in Spanish cropland and pastureland (Gg)

\begin{tabular}{|c|c|c|c|c|c|c|c|c|c|c|c|c|c|c|c|c|c|c|}
\hline & \multicolumn{3}{|c|}{ Crop residues } & \multirow{2}{*}{$\frac{\text { Rainfall }}{\mathrm{N}}$} & \multirow{2}{*}{ 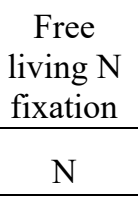 } & \multirow{2}{*}{$\begin{array}{c}\begin{array}{c}\text { Symbiotic } \\
\text { N fixation }\end{array} \\
\mathrm{N}\end{array}$} & \multicolumn{3}{|c|}{ Irrigation } & \multicolumn{3}{|c|}{ Mineral fertilizers } & \multicolumn{3}{|c|}{ Manure/Excretions } & \multicolumn{3}{|c|}{ Seeds } \\
\hline & $\mathrm{N}$ & $\mathrm{P}$ & $\mathrm{K}$ & & & & $\mathrm{N}$ & $\mathrm{P}$ & $\mathrm{K}$ & $\mathrm{N}$ & $\mathrm{P}$ & $\mathrm{K}$ & $\mathrm{N}$ & $\mathrm{P}$ & $\mathrm{K}$ & $\mathrm{N}$ & $\mathrm{P}$ & $\mathrm{K}$ \\
\hline \multicolumn{19}{|c|}{ Cropland } \\
\hline 1960 & 40 & 8 & 76 & 168 & 41 & 160 & 21 & 0.3 & 22 & 274 & 129 & 69 & 237 & 58 & 194 & 17 & 3 & 4 \\
\hline 1970 & 37 & 9 & 88 & 189 & 42 & 157 & 25 & 0.4 & 26 & 602 & 179 & 180 & 227 & 58 & 192 & 23 & 4 & 5 \\
\hline 1980 & 64 & 13 & 142 & 245 & 41 & 178 & 32 & 0.5 & 33 & 874 & 188 & 225 & 305 & 72 & 208 & 21 & 4 & 4 \\
\hline 1990 & 106 & 18 & 218 & 261 & 40 & 170 & 36 & 0.5 & 38 & 1043 & 225 & 307 & 331 & 82 & 245 & 24 & 4 & 4 \\
\hline 2000 & 153 & 21 & 266 & 266 & 37 & 179 & 30 & 0.5 & 31 & 1120 & 263 & 404 & 490 & 121 & 337 & 23 & 4 & 4 \\
\hline 2008 & 164 & 22 & 292 & 248 & 35 & 140 & 30 & 0.5 & 37 & 884 & 162 & 279 & 528 & 131 & 355 & 30 & 5 & 6 \\
\hline No-import & 153 & 21 & 266 & 255 & 37 & 179 & 30 & 0.5 & 31 & 1120 & 263 & 404 & 333 & 82 & 229 & 23 & 4 & 4 \\
\hline \multicolumn{19}{|c|}{ Pastureland } \\
\hline 1960 & & & & 131 & 64 & 119 & & & & & & & 219 & 30 & 154 & & & \\
\hline 1970 & & & & 136 & 60 & 113 & & & & & & & 121 & 17 & 88 & & & \\
\hline 1980 & & & & 176 & 59 & 110 & & & & & & & 108 & 15 & 76 & & & \\
\hline 1990 & & & & 186 & 58 & 108 & & & & & & & 169 & 23 & 123 & & & \\
\hline 2000 & & & & 226 & 62 & 116 & & & & & & & 219 & 30 & 153 & & & \\
\hline 2008 & & & & 213 & 59 & 111 & & & & & & & 221 & 31 & 152 & & & \\
\hline No-import & & & & 216 & 62 & 116 & & & & & & & 172 & 24 & 120 & & & \\
\hline
\end{tabular}


Table A1.5. Outputs of N, P and K in Spanish cropland and pastureland (Gg)

\begin{tabular}{|c|c|c|c|c|c|c|}
\hline & \multicolumn{3}{|c|}{ Harvest/Grazing } & \multirow{2}{*}{$\begin{array}{c}\text { Denitrification } \\
\mathrm{N}\end{array}$} & \multirow{2}{*}{$\frac{\begin{array}{c}\mathrm{NH}_{3} \\
\text { volatilization }\end{array}}{\mathrm{N}}$} & \multirow{2}{*}{$\begin{array}{c}\text { Leaching } \\
\mathrm{N}\end{array}$} \\
\hline & $\mathrm{N}$ & $\mathrm{P}$ & $\mathrm{K}$ & & & \\
\hline & \multicolumn{6}{|c|}{ Cropland } \\
\hline 1960 & 517 & 83 & 473 & 107 & 92 & 74 \\
\hline 1970 & 611 & 98 & 560 & 122 & 115 & 139 \\
\hline 1980 & 716 & 115 & 654 & 137 & 148 & 199 \\
\hline 1990 & 849 & 136 & 757 & 145 & 165 & 235 \\
\hline 2000 & 898 & 144 & 828 & 150 & 199 & 263 \\
\hline 2008 & 891 & 144 & 821 & 138 & 185 & 219 \\
\hline \multirow[t]{2}{*}{ No-import } & 898 & 144 & 828 & 143 & 172 & 251 \\
\hline & \multicolumn{6}{|c|}{ Pastureland } \\
\hline 1960 & 273 & 32 & 286 & 74 & 44 & 18 \\
\hline 1970 & 90 & 10 & 94 & 66 & 33 & 10 \\
\hline 1980 & 68 & 8 & 71 & 64 & 32 & 9 \\
\hline 1990 & 73 & 8 & 76 & 65 & 37 & 13 \\
\hline 2000 & 125 & 14 & 131 & 72 & 43 & 18 \\
\hline 2008 & 117 & 14 & 123 & 69 & 42 & 18 \\
\hline No-import & 125 & 14 & 131 & 70 & 39 & 14 \\
\hline
\end{tabular}

